\title{
Enterobacter agglomerans (Beijerinck) comb. nov. (the Herbicola-Lathyri Bacteria)
}

\author{
W. H. EWING and M. A. FIFE
}

Center for Disease Control, Atlanta, Georgia 30333

\begin{abstract}
The biochemical reactions given by 361 strains of herbicolala-thyri bacteria were studied and reported. The microorganisms were categorized into 11 principal biogroups on the basis of reduction of nitrate and their VogesProskauer and indole reactions. The taxonomic positions and the nomenclature of the bacteria were discussed in detail, and the microorganisms were classified in the genus Enterobacter as Enterobacter agglomerans (Beijerinck) comb. nov. NCTC 9381 (ATCC 27155; CDC 1461-67) was designated as the neotype strain of the species.
\end{abstract}

The reports of several investigators indicated that certain gram-negative bacteria, which have been classified in the genus Erwinia in the past, occur with some degree of frequency in specimens from various disease processes in man and lower animals. In addition to being gram negative, these particular bacillary forms are peritrichously flagellated, fermentative, and frequently are chromogenic (yellow). These bacteria first were isolated from plants, seeds, and fruits, and a number of specific epithets were assigned to them. Usually these epithets were derived from the plant sources of the isolants. As mentioned by Graham and Hodgkiss (17), the name best know to agricultural bacteriologists is Bacterium herbicola or Erwinia herbicola. The first of these names, generally attributed to Löhnis (1911; cited by Graham and Hodgkiss, reference 17), is derived from $B$. herbicola aureum, introduced by Düggeli (9). However, plant pathologists perhaps are more familiar with the name $E$. lathyri, which is derived from $B$. lathyri (Manns and Taubenhaus, 1913; cited by Graham and Hodgkiss, reference 17).

The first isolation from humans of microorganisms of this sort that can be authenticated apparently was made by Dresel and Stickl (8), who recovered the bacteria from stool specimens from patients with typhoid fever and named them "Typhusbazillen." Strains of this bacterium were studied by Cruickshank (6), and he and other bacteriologists isolated similar cultures from a number of sources, including specimens from humans. Graham and Hodgkiss (17) directed attention to the similarity of cultures described as $B$. typhi flavum and the chromagenic bacteria variously known as $E$. herbicola, $E$. lathyri, $E$. ananas, $E$. cassavae, $E$. milletiae, and $E$. uredovora. These investigators also examined strains isolated by Muraschi et al. (21) from the internal organs of deer and from human throats and concluded that these isolants were similar to $E$. herbicola and B. typhi flavum.

Another microorganism that should be mentioned is Pseudomonos trifolii described by Hüss (18), who stated that its flagellation was polar. James (19) transferred this bacterium to the genus Xanthomonas, but retained the specific epithet trifolii, whereas Gorlenko (1968; cited by Graham and Hodgkiss, reference 17) employed the name $X$. herbicola. Dye (10) reported that the flagellation of $X$. trifolii was peritrichous, not polar as previously described. Since the flagellation, cultural, and biochemical properties of $X$. trifolii and $E$. lathyri were similar, Dye (10) suggested that both of these bacteria should be classified as $E$. herbicola. Komagata et al. (20) examined cultures identified as $X$. trifolii and arrived at similar conclusions.

Readers are referred to the publications of Graham and Hodgkiss (17) and Ewing and Fife (CDC Publ., in press) for additional references concerning the occurrence and distribution of the microorganisms under discussion.

This publication summarizes investigations 
into the biochemical reactions given by relatively large numbers of herbicola-lathyri bacteria (anaerogenic and aerogenic forms). In addition, proposals are made regarding the taxonomic position and nomenclature of the bacteria and the designation of the neotype strain.

\section{MATERIALS AND METHODS}

Between 1949 and the end of 1970, 361 strains of herbicola-lathyri bacteria were received for identification or examination in the Enteric Bacteriology Laboratories. Thirty-four of the anaerogenic isolants were from the collection of Dennis C. Graham (see Acknowledgment). Of these, 22 were recovered from various plant sources, 7 (including 5 labeled $B$. typhi flavum) were isolated from humans, and 5 were from internal organs of deer (23). Of the 327 strains received for identification in the Enteric Bacteriology Laboratories, 239 originated in specimens (primarily wounds, blood, urine, sputa) from humans, 22 were recovered from various species of animals, and the remainder were from foods or environment, or were of unknown origin. Additional information about the sources of the 361 isolates may be found in the publications of Ewing and Fife (CDC Publ., in press).

The methods employed in the examination of the 361 strains were the same as those described by Ewing and Davis (12) and Ewing and Edwards (13) and were similar to those used by Graham and Hodgkiss (17). Unless otherwise indicated, cultures were incubated at 35 to $37 \mathrm{C}$.

\section{RESULTS}

The results obtained in the examination of the 361 isolants of herbicola-lathyri bacteria are summarized in Tables 1 and 2 . In Table 1 the reactions given by anaerogenic and aerogenic strains are listed separately for comparison.

The data presented in Table 2 indicated that all of the strains were fermentative, that none produced indophenol oxidase, and that evidence of pectinolytic, lipolytic, or alginolytic activity was not detected in any strain. Hydrogen sulfide was not produced in Triple SugarIron or peptone-iron-agar media during the usual period of incubation (12). Most (70.6\%) of the isolates produced yellow pigment on ordinary nutritive media, reduced nitrate to nitrite $(84.6 \%)$, failed to form indole $(80.3 \%)$, grew on Simmons' citrate-agar medium $(61.8 \%)$, were motile $(87.5 \%)$, and liquefied gelatin $(81.7 \%)$. With rare exceptions, acid was not produced in Jordan's tartrate medium, and none of the isolates gave evidence of lysine, arginine, or ornithine decarboxylase activity.
The majority were anaerogenic $(80.9 \%)$.

It was possible to separate 288 of the 292 anaerogenic strains (Table 1) into seven biogroups on the basis of reduction of nitrate to nitrite, production of indole, and the results of Voges-Proskauer (VP) tests as shown in Table 3. (Unfortunately, tests for reduction of nitrate were not performed with four strains when they were received, and stock cultures of these four were lost.)

The aerogenic strains (Table 1) were divisible into four biogroups as shown in Table 4 .

The reactions obtained with members of the 11 delineated biogroups in selected tests are given in detail in the publications of Ewing and Fife (CDC Publ., in press).

The results obtained with 34 of the 35 strains reported upon by Graham and Hodgkiss (17) indicated that these strains belonged to six of the seven anaerogenic biogroups. Twenty-one belonged to biogroup 1, and smaller numbers were members of the other biogroups, except biogroup three, which was not represented. With regard to the specific epithets that appeared on the labels of this group of 34 isolants, with one exception, strains labeled with different species names were members of a single biogroup and isolates labeled with the same specific epithet belonged to different biogroups. The exception was that four strains labeled $E$. ananas were members of biogroup 4 (Ewing and Fife, CDC Publ., in press). All of the strains received from T. F. Muraschi (23) belonged to biogroup 1 .

As stated elsewhere (13), the indications are that the genus Erwinia, as presented in editions of Bergey's Manual (4), is composed of at least four categories or groups of bacteria. The first is the true erwinia, exemplified by $E$. amylovora, which Waldee (24) placed in a separate family (Erwiniaceae). The second group is composed of pectolytic bacteria formerly classified as Erwinia carotovora, etc. On the basis of proposals made by several investigators $(7,15,16,24)$ and on the basis of the authors' studies, these pectolytic microorganisms were placed in the genus Pectobacterium Waldee (24) and the tribe Klebsielleae $(11,13$; unpublished data of the authors). The third of the aforementioned bacterial groups is a heterogeneous collection of microorganisms identified as enterobacters, klebsiellas, etc. Clearly, these should be classified in the genera of Enterobacteriaceae in which they belong.

The last of the four groups of microorganisms is composed of the herbicola-lathyri 
TABLE 1. Biochemical reactions of anaerogenic and aerogenic strains of Enterobacter agglomerans

\begin{tabular}{|c|c|c|c|c|c|c|}
\hline \multirow[b]{2}{*}{ Test or substrate } & \multicolumn{3}{|c|}{ Anaerogenic (292) } & \multicolumn{3}{|c|}{ Aerogenic (69) } \\
\hline & Reaction $^{a}$ & Per cent + & $\begin{array}{c}\text { Per } \\
\text { cent }+)^{b}\end{array}$ & Reaction & Per cent + & $\begin{array}{c}(\text { Per } \\
\text { cent }+)^{b}\end{array}$ \\
\hline Hydrogen sulfide $\ldots \ldots \ldots \ldots$ & - & 0 & & - & 0 & \\
\hline Urease $\ldots \ldots \ldots \ldots \ldots \ldots$ & d & 20.5 & $(10.3)$ & - or + & 46.4 & \\
\hline Indole $\ldots \ldots \ldots \ldots \ldots \ldots$ & - or + & 16.8 & & - or + & 31.9 & \\
\hline Methyl red $(37 \mathrm{C}) \ldots \ldots \ldots$ & - or + & 46.9 & & - or + & 43.5 & \\
\hline Voges-Proskauer (37 C) ...... & + or - & 66.1 & & + or - & 59.4 & \\
\hline Citrate (Simmons') $\ldots \ldots \ldots \ldots$ & d & 62.3 & (26.4) & d & 59.4 & $(5.8)$ \\
\hline $\mathrm{KCN} \ldots \ldots \ldots \ldots \ldots \ldots \ldots$ & - or + & 34.4 & & + or - & 63.8 & \\
\hline Motility $\ldots \ldots \ldots \ldots \ldots$ & + or - & 87.7 & & + or - & 87 & \\
\hline Gelatin $(22 \mathrm{C}) \ldots \ldots \ldots \ldots$ & $\mathrm{d}$ & 3.5 & $(82.9)$ & $\mathrm{d}$ & 5.8 & $(56.5)$ \\
\hline Lysine decarboxylase $\ldots \ldots \ldots$ & - & 0 & & - & $\mathbf{0}$ & \\
\hline Arginine dihydrolase $\ldots \ldots \ldots$ & - & 0 & & - & 0 & \\
\hline Ornithine decarboxylase $\ldots \ldots$ & - & 0 & & - & 0 & \\
\hline Phenylalanine deaminase ..... & - or + & 30 & & - or + & 17.4 & \\
\hline Glucose:acid ........... & + & 100 & & + & 100 & \\
\hline gas $\ldots \ldots \ldots \ldots \ldots \ldots$ & - & 0 & & + & 100 & \\
\hline Lactose $\ldots \ldots \ldots \ldots \ldots$ & d & 32.9 & $(9.6)$ & + & 94.2 & (2.9) \\
\hline Sucrose $\ldots \ldots \ldots \ldots \ldots$ & $\mathrm{d}$ & 72.5 & $(1.8)$ & $\mathrm{d}$ & 68.1 & $(4.4)$ \\
\hline Mannitol .............. & + & 100 & & + & 100 & \\
\hline Dulcitol ............... & - & 1.7 & $(0.7)$ & + or - & 56.5 & \\
\hline Salicin $\ldots \ldots \ldots \ldots \ldots \ldots$ & $\mathrm{d}$ & 60.2 & $(20.6)$ & + & 98.5 & \\
\hline Adonitol $\ldots \ldots \ldots \ldots \ldots$ & - & 3.4 & & - or + & 27.6 & \\
\hline Inositol $\ldots \ldots \ldots \ldots \ldots \ldots$ & $d$ & 20.5 & $(6.2)$ & $\mathrm{d}$ & 8.7 & (2.9) \\
\hline Sorbitol .............. & d & 17.4 & $(0.4)$ & + or - & 62.3 & \\
\hline Arabinose $\ldots \ldots \ldots \ldots \ldots$ & + & 97.2 & $(0.4)$ & + & 97.1 & \\
\hline Raffinose $\ldots \ldots \ldots \ldots \ldots$ & d & 19.8 & $(4.5)$ & $\mathrm{d}$ & 65.2 & (1.5) \\
\hline Rhamnose $\ldots \ldots \ldots \ldots \ldots$ & d & 80.2 & $(6.3)$ & + & 100 & \\
\hline Malonate $\ldots \ldots \ldots \ldots \ldots$ & + or - & 66.8 & & + or - & 58.8 & \\
\hline Mucate $\ldots \ldots \ldots \ldots \ldots$ & - or + & 36.6 & & + or - & 75 & \\
\hline Jordan's tartrate ......... & - & 0 & & - or + & 10.3 & \\
\hline Sodium acetate $\ldots \ldots \ldots \ldots$ & d & 13.5 & $(29.2)$ & $\mathrm{d}$ & 67.7 & $(5.9)$ \\
\hline Sodium alginate $\ldots \ldots \ldots \ldots$ & - & 0 & & - & 0 & \\
\hline Lipase, corn oil . . . . . . . . & - & 0 & & - & 0 & \\
\hline Sodium pectate $\ldots \ldots \ldots \ldots$ & - & 0 & & - & 0 & \\
\hline Maltose $\ldots \ldots \ldots \ldots \ldots$ & + or $(+)$ & 84.8 & $(5.2)$ & + & 100 & \\
\hline Xylose ............. & + or $(+)$ & 88.8 & (4.5) & + & 95.6 & \\
\hline Cellobiose $\ldots \ldots \ldots \ldots \ldots$ & $\mathrm{d}$ & 42.8 & (20.3) & + & 94.2 & (2.9) \\
\hline Glycerol $\ldots \ldots \ldots \ldots \ldots \ldots$ & $\mathrm{d}$ & 20.2 & $(30.4)$ & $\mathrm{d}$ & 32.3 & (36.8) \\
\hline Alpha methyl glucoside & - & 3.6 & (1.4) & $\mathrm{d}$ & 20.6 & $(2.9)$ \\
\hline Erythritol $\ldots \ldots \ldots \ldots$ & - & 0 & & - & 0 & \\
\hline Esculin $\ldots \ldots \ldots \ldots \ldots$ & d & 59.4 & $(24.2)$ & + & 92.6 & \\
\hline Nitrate to nitrite $\ldots \ldots \ldots$ & + or - & 81.7 & & + & 97.1 & \\
\hline Oxidation-fermentation $\ldots$ & $\mathrm{F}$ & 100 & & $\mathrm{~F}$ & 100 & \\
\hline Oxidase $\ldots \ldots \ldots \ldots \ldots$ & - & 0 & & - & 0 & \\
\hline Cetrimide $\ldots \ldots \ldots \ldots$ & - & 1.8 & & - & 2.9 & \\
\hline Pigment (yellow) . . . . . . & + or - & 73.6 & & + or - & 58 & \\
\hline Organic acids $\ldots \ldots \ldots \ldots$ & & & & & & \\
\hline citrate $\ldots \ldots \ldots \ldots \ldots$ & - & 0.4 & $(2.8)$ & d & 37.7 & (11.8) \\
\hline D-tartrate $\ldots \ldots \ldots \ldots \ldots$ & - & 0.4 & $(2.8)$ & d & 4.4 & (5.9) \\
\hline
\end{tabular}

${ }^{a}$ Symbols:,$+ 90 \%$ or more positive within 1 or 2 days of incubation; $(+)$, positive reaction after 3 or more days (decarboxylase tests: 3 or 4 days); -, no reaction $(90 \%$ or more); + or - , majority of strains positive, some cultures negative; - or + , majority of cultures negative, some strains positive; $(+)$ or + , majority of reactions delayed, some occur with 1 or 2 days; d, different reactions: $+,(+),-$.

$b$ Figures in parentheses indicate percentages of delayed reactions ( 3 or more days).

bacteria. In the past, the numerous so-called species of these bacteria were classified in the genus Erwinia in various editions of Bergey's Manual (4), although a few were placed in other genera such as Xanthomonas, Pseudomonas, or Flavobacterium. With few exceptions, these species were named in accordance with the plant host (or source) from which they were 
TABLE 2. Summary of the biochemical reactions of Enterobacter agglomerans (361 strains) and the neotype strain (NCTC 9381)

\begin{tabular}{|c|c|c|c|c|}
\hline \multirow[b]{2}{*}{ Test or substrate } & \multicolumn{3}{|c|}{ E. agglomerans ${ }^{a}$} & \multirow{2}{*}{$\begin{array}{c}\begin{array}{c}\text { Neotype strain } \\
\text { (ATCC 27155, NCTC 9381) }\end{array} \\
\text { Reaction }\end{array}$} \\
\hline & Reaction & Per cent + & $(\%+)$ & \\
\hline Hydrogen sulfide $\ldots \ldots \ldots \ldots \ldots$ & - & 0 & & - \\
\hline Urease $\ldots \ldots \ldots \ldots \ldots \ldots \ldots$ & $\mathrm{d}$ & 25.8 & (8.3) & - \\
\hline Indole $\ldots \ldots \ldots \ldots \ldots \ldots \ldots$ & - or + & 19.7 & & - \\
\hline Methyl red $(37 \mathrm{C}) \ldots \ldots \ldots \ldots$ & - or + & 46.3 & & - \\
\hline Voges-Proskauer $(37 \mathrm{C}) \ldots \ldots \ldots$ & + or - & 64.8 & & + \\
\hline Citrate (Simmons') $\ldots \ldots \ldots \ldots \ldots$ & $\mathrm{d}$ & 61.8 & $(22.4)$ & + \\
\hline $\mathrm{KCN}, \ldots \ldots \ldots \ldots \ldots \ldots \ldots$, & - or + & 40 & & - \\
\hline Motility (peritrichous cells) $\ldots \ldots \ldots$ & +or - & 87.5 & & + (see Fig. 1) \\
\hline Gelatin $(22 \mathrm{C}) \ldots \ldots \ldots \ldots \ldots \ldots$ & d & 3.9 & (77.8) & $(+)$ \\
\hline Lysine decarboxylase $\ldots \ldots \ldots \ldots$ & - & 0 & & - \\
\hline Arginine hihydrolase $\ldots \ldots \ldots \ldots$. & - & 0 & & - \\
\hline Ornithine decarboxylase $\ldots \ldots \ldots$ & - & 0 & & - \\
\hline Phenylalanine deaminase $\ldots \ldots \ldots$. & - or + & 27.6 & & - \\
\hline Glucose:acid $\ldots \ldots \ldots \ldots \ldots \ldots$ & + & 100 & & + \\
\hline gas $\ldots \ldots \ldots \ldots \ldots \ldots \ldots \ldots$ & - or + & 19.1 & & - \\
\hline Lactose $\ldots \ldots \ldots \ldots \ldots \ldots$ & d & 44.6 & (8.3) & - \\
\hline Sucrose $\ldots \ldots \ldots \ldots \ldots \ldots \ldots$ & d & 71.7 & (2.2) & + \\
\hline Mannitol $\ldots \ldots \ldots \ldots \ldots \ldots$ & + & 100 & & + \\
\hline Dulcitol $\ldots \ldots \ldots \ldots \ldots \ldots \ldots$ & d & 12.3 & $(0.6)$ & - \\
\hline Salicin $\ldots \ldots \ldots \ldots \ldots \ldots \ldots$ & $\mathrm{d}$ & 67.6 & (13.9) & + \\
\hline Adonitol:acid ....... & - & 7.5 & & - \\
\hline gas $\ldots \ldots \ldots \ldots \ldots \ldots \ldots$ & - & 3.9 & & - \\
\hline Inositol:acid $\ldots \ldots \ldots \ldots \ldots \ldots$ & d & 18.3 & $(5.5)$ & - \\
\hline gas $\ldots \ldots \ldots \ldots \ldots \ldots \ldots$ & - & 1.4 & $(0.3)$ & - \\
\hline Sorbitol $\ldots \ldots \ldots \ldots \ldots \ldots \ldots$ & d & 26 & $(0.3)$ & - \\
\hline Arabinose $\ldots \ldots \ldots \ldots \ldots \ldots$ & + & 97.2 & $(0.3)$ & + \\
\hline Raffinose $\ldots \ldots \ldots \ldots \ldots \ldots$. & $\mathrm{d}$ & 28.5 & (3.9) & - \\
\hline Rhamnose $\ldots \ldots \ldots \ldots \ldots \ldots$ & d & 84 & (5.1) & + \\
\hline Malonate $\ldots \ldots \ldots \ldots \ldots \ldots$ & + or - & 65.3 & & + \\
\hline Mucate $\ldots \ldots \ldots \ldots \ldots \ldots \ldots$ & - or + & 44 & & - \\
\hline Jordan's tartrate $\ldots \ldots \ldots \ldots \ldots$ & - & 1.9 & & - \\
\hline Sodium acetate $\ldots \ldots \ldots \ldots \ldots$ & $\mathrm{d}$ & 24.1 & $(24.6)$ & - \\
\hline Sodium alginate $\ldots \ldots \ldots \ldots \ldots$ & - & 0 & & - \\
\hline Lipase, corn oil .............. & - & 0 & & - \\
\hline Sodium pectate $\ldots \ldots \ldots \ldots \ldots$ & - & 0 & & - \\
\hline Maltose $\ldots \ldots \ldots \ldots \ldots \ldots \ldots$ & + or $(+)$ & 87.7 & (4.2) & + \\
\hline Xylose $\ldots \ldots \ldots \ldots, \ldots, \ldots$ & + & 90.1 & (3.7) & + \\
\hline Cellobiose:acid $\ldots \ldots \ldots \ldots \ldots$. & $\mathrm{d}$ & 52.6 & (17) & $(+)$ \\
\hline gas $\ldots \ldots \ldots \ldots \ldots \ldots \ldots$ & - or + & 17.3 & & - \\
\hline Glycerol:acid $\ldots \ldots \ldots \ldots \ldots$ & d & 22.5 & (31.6) & - \\
\hline gas $\ldots \ldots \ldots \ldots \ldots \ldots \ldots$ & - & 3.7 & $(0.8)$ & - \\
\hline Alpha methyl glucoside ........ & - & 6.9 & (1.7) & - \\
\hline Erythritol $\ldots \ldots \ldots \ldots \ldots \ldots$ & - & 0 & & - \\
\hline 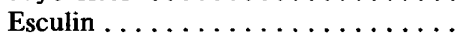 & $\mathrm{d}$ & 65.9 & $(19.5)$ & + \\
\hline Nitrate to nitrite $\ldots \ldots \ldots \ldots \ldots$ & +or - & 84.6 & & + \\
\hline Oxidation-fermentation.$\ldots \ldots \ldots$ & $\mathrm{F}$ & 100 & & $\mathrm{~F}$ \\
\hline Oxidase $\ldots \ldots \ldots \ldots \ldots \ldots \ldots$ & - & 0 & & - \\
\hline Cetrimide $\ldots \ldots \ldots \ldots \ldots \ldots$ & - & 2 & & - \\
\hline Pigment (yellow) $\ldots \ldots \ldots \ldots \ldots$ & +or - & 70.6 & & + \\
\hline Organic acids $\ldots \ldots \ldots \ldots \ldots \ldots$ & & & & \\
\hline citrate $\ldots \ldots \ldots \ldots \ldots \ldots \ldots \ldots$ & d & $\begin{array}{l}8.1 \\
1.2\end{array}$ & $\begin{array}{l}(4.7) \\
(3.5)\end{array}$ & $\begin{array}{l}- \\
-\end{array}$ \\
\hline
\end{tabular}

${ }^{a}$ See Table 1 , footnote $a$, for explanation of symbols. 


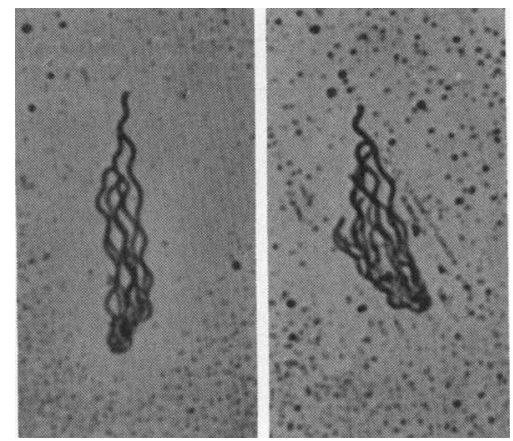

Fig. 1. Peritrichous cells of Enterobacter agglomerans ATCC 27155. Twenty-four-hour broth culture at 26 C. Staining by Leifson's method. $\times 1,200$.

recovered. This practice resulted in similar microorganisms being labeled with different species names in many instances. The results of work described herein and reports of other investigators (17) indicated that the herbicolalathyri bacteria are, indeed, members of the family Enterobacteriaceae. Of this there can be little doubt. The authors are not concerned by the fact that only about $82 \%$ of the anaerogenic herbicola-lathyri bacteria reduced nitrate to nitrite (Table 1) since the addition of these microorganisms to the family Enterobacteriaceae would not appreciably alter the percentage of positive nitrate reactions given by members of the family as a whole.

Since it was possible to divide the herbicolalathyri bacteria into a number of biogroups, it might appear that these bacteria are heterogeneous and that they might be assigned to several different genera, as suggested by some investigators. However, careful examination of the data obtained indicated that many of the cultural and biochemical characteristics of the herbicola-lathyri bacteria were quite uniform (Tables 1 and 2). These observations confirmed the views of Graham and Hodgkiss (17). When the reactions obtained with members of the various biogroups were compared with those given by members of the several genera of Enterobacteriaceae, it was apparent that they should not be assigned to several different genera. On the contrary, when the aggregate characteristics of the herbicola-lathyri bacteria are considered, it is seen that these bacteria resemble members of the genus Enterobacter in many important respects. Comparison of the reactions obtained with strains of herbicolalathyri bacteria with those given by the species Enterobacter cloacae, Enterobacter aerogenes, Enterobacter hafniae, and Enterobacter liquefaciens (for example, see Table 20 of reference 14) led the authors to conclude that the herbicola-lathyri bacteria (both anaerogenic and aerogenic biogroups) should be incorporated into the genus Enterobacter as an additional species. In fact, the genus Enterobacter is the only existing genus of the family Enterobacteriaceae into which these bacteria can be incorporated.

Conceivably, the herbicola-lathyri bacteria could be placed in a newly erected genus within the family Enterobacteriaceae. However, the authors are of the opinion that such a proposal should not be made, certainly not at present. First, the similarity of these microorganisms and the species of Enterobacter must be considered, as mentioned above. Second, if the herbicola-lathyri bacteria were placed in a new genus and later it was decided that they were members of an existing genus (e.g., Enterobacter), transfer of the microorganisms to that genus would leave a generic name in the literature which might cause confusion for several years. Conversely, transfer of the species from Enterobacter to a new genus could be effected without difficulty.

Since the aggregate biochemical reactions given by the anaerogenic and aerogenic herbicola-lathyri bacteria are similar in many respects (Table 1), the authors believe that both should be placed in the same species. This species may be divided later, if necessary, but a need for more than one species or for subspecies is at present not apparent. The characteristics of 361 strains that belonged to these two major biogroups (anaerogenic and

TABLE 3. Biogroups of anaerogenic strains

\begin{tabular}{c|c|c|c|c}
\hline .Biogroup & Nitrate & Indole & VP $^{a}$ & $\begin{array}{c}\text { No. of } \\
\text { strains }\end{array}$ \\
\hline 1 & + & - & + & 157 \\
2 & + & - & - & 52 \\
3 & - & - & - & 21 \\
4 & - & + & + & 19 \\
5 & + & + & - & 19 \\
6 & - & - & + & 12 \\
7 & + & + & + & 8 \\
\hline
\end{tabular}

${ }^{a}$ Voges-Proskauer.

TABLE 4. Biogroups of aerogenic strains

\begin{tabular}{c|c|c|c}
\hline Biogroup & Indole & $\mathrm{VP}^{a}$ & No. of strains \\
\hline G1 & + & - & 33 \\
G2 & - & - & 15 \\
G3 & - & + & 15 \\
G4 & + & + & 6 \\
\hline
\end{tabular}

${ }^{a}$ Voges-Proskauer. 
aerogenic) of herbicola-lathyri bacteria are summarized in Table 2. The data given in this table should be compared to similar data for the existing species of Enterobacter (for example, see Tables 10 to 20 in the publication of Fife et al., reference 14).

Inclusion of bacteria that differ with respect to indole production and the results of VP tests in a single species might seem unreasonable to some. However, bacteria that yield such reactions presently are included in species of Enterobacteriaceae and in species within other families of bacteria as well.

Selection of the correct specific epithet for use with the generic term Enterobacter in the species name of the herbicola-lathyri bacteria presented a slight, but not insurmountable, problem. Although numerous epithets have been used for the herbicola-lathyri bacteria, the correct choice is between two, agglomerans and trifolii. B. herbicola aureum (9) clearly is not a validly published name, and corrected forms of this name, such as Bacterium herbicola (Löhnis, 1911 , cited in reference 17 ) and $E$. herbicola (Geilinger) Dye (10), all contain specific epithets that are later than agglomerans or trifolii. The specific epithets in other names, e.g., E. lathyri (Manns and Taubenhaus, 1913, cited in reference 17 ) also are later than these two (v. inf.).

The possible synonymy of Bacillus agglomerans Beijerinck (1) is mentioned on page 173 of the sixth edition of Bergey's Manual (3), wherein it is stated that $B$. agglomerans is said by Beijerinck (2) to be identical with $B$. herbicola of Burri and of Düggeli. Further, it is stated (3) that, if this is so, the name $B$. agglomerans (1) has priority. According to Index Bergeyana (5), this name was validly published.

Referring to a microorganism which he called Bacillus luteoalbus, Beijerinck (1) states: "Since the number of colonies found never was large, there is a chance that this kind of bacillus occurred only in rents [presumably damaged areas] which had escaped notice, or in intercellular spaces.

"This last observation also applies to the putrefacient bacillus, obtained from red clover, which is motile, brownish and slightly liquefacient [presumably with respect to gelatin] and resembles diplococcus. This putrefacient bacillus I call Bacillus agglomerans, because the shape of its colonies is peculiarly reminiscent of Proteus."

A translation of Beijerinck's (2) statement regarding the identity of his B. agglomerans (1) and the bacteria mentioned by Burri and Düggeli follows:

"This, perhaps, is the best place for me to pass on a few remarks on the common saprophytic flora of higher plants in general.

"Burri and Düggeli are of the opinion that not only the chief role but, as it were, the exclusive role is played by a certain kind of bacterium-which they have called Bacillus herbicola [actually, of course, Bacterium herbicola aureum in Düggeli's paper, which Beijerinck is writing about]. It is true, I fully recognize the universality of this bacteriumwhich I discovered many years ago and which I have called $B$. anglomerans [variant spelling]. And yet, after extensive analyses, I have arrived at the conclusion that other microbes likewise may play a similar role.

"For the purpose of ascertaining the presence and distribution of $B$. anglomerans [sic] $(=B$. herbicola), I should like to recommend the following useful procedure:-take seeds of any plant (clover, wheat, hemp, flax, Brassica, Vicia, Phalaris and many others which were subjected to analysis) and allow them to germinate fully on moist blotting paper in an incubator at $25-30^{\circ} \mathrm{C}$. As soon as the root of the germ appears, many cells of the calyptra are shed; in the ensuing slimy substance the bacterium develops almost without fail, because it can stand drying very well, and occurs in the dust of the seed coat. The only thing one has to do is to pick up, with a pair of forceps, the seeds that have germinated, and streak the root tips over a gelatine plate, e.g., meat gelatine. After 1 or 2 days one will get a whole series of colonies-often $B$. anglomerans [sic] only, but sometimes with other common bacteria. One can easily recognize this kind of bacterium because of highly characteristic zooglea (which, however, in quite similar forms, may occur in other kinds of bacteria), and in most cases also because of the yellow or light-brown color of the colonies; this kind of bacterium, however, also occurs colorless, which makes the diagnosis slightly more difficult." [The zoogleal masses referred to may have been symplasmata.]

The synonymy of $P$. trifolii (18) and $B$. herbicola aureum (Dügelli) also is mentioned on page $173(3,18)$. Data in the literature, e.g., Komagata et al. (20), clearly indicate that $P$. trifolii is a member of the herbicola-lathyri bacteria. [In the authors' hands, a strain (ATCC 12287 ) labeled $X$. trifolii proved to be a typical strain of $E$. agglomerans, biogroup 1.] Since the name $P$. trifolii was validly published and is legitimate (5), the epithet trifolii has priority over herbicola, lathyri, etc.

Both $B$. agglomerans and $P$. trifolii originally were described as polarly flagellated microorganisms. In the case of the latter, this description has been shown to be erroneous $(10,20)$. Further, these two bacterial species 
were characterized as rapid liquefiers of gelatin which reduced nitrate to nitrite and produced yellow pigment.

The authors have been unable to locate an authentic strain of $B$. agglomerans in Holland or elsewhere. Nevertheless, only one course is open: to employ the epithet agglomerans as used by Beijerinck in 1888 (11). The authors believe that this course is reasonable and correct. It might be maintained that $B$. agglomerans Beijerinck could not have been one of the herbicola-lathyri bacteria because it was described as a polarly flagellated microorganism. However, some investigators characterized several of the herbicola-lathyri bacteria, including $P$. trifolii, as polarly flagellated and classified them as pseudomonads or as xanthomonads. The authors believe that credence must be given to Beijerinck's statement that $B$. agglomerans was identical with $B$. herbicola aureum of Burri and Düggeli. This investigator was in a position to make the comparison, and it must be assumed that his assessment of the identity of the bacteria was correct. Although some investigators may prefer another specific epithet for these microorganisms and others may feel that the epithet selected is unsuitable or inappropriate, these factors have no bearing on the selection of the correct name of a microorganism.

For the reasons given, the authors elected to employ the specific epithet agglomerans in the name of the proposed species of Enterobacter to which the microorganisms herein referred to as the herbicola-lathyri bacteria are assigned. Therefore, the correct name for this species is Enterobacter agglomerans (Beijerinck) comb. nov., and NCTC 9381 (ATCC 27155; CDC 1461-67) is designated as the neotype strain. Originally, this strain was called $B$. typhi flavum. It is a member of biogroup 1.

The following is a list (no doubt incomplete) of synonyms of Enterobacter agglomerans:

Bacillus agglomerans Beijerinck 1888, Bacterium herbicola aureum Düggeli 1904 (9), Pseudomonas trifolii Hüss 1907 (18), Bacterium herbicola Löhnis 1911 (3, 5, 17), Bacterium herbicola Geilinger 1921 (3, 5, 17), Flavobacterium trifolium (Hüss) Bergey et al. 1923 (3, 5, 17), Pseudomonas herbicola (Geilinger) d'Rossi 1927 (3, 5, 17), Erwinia ananas Serrano 1928 (3, 5, 17), Erwinia erivanensis (Kalantarian) Bergey et al. 1930 (3, 5, 17), Erwinia flavida (Fawcett) Magrou 1937 (3, 5, 17), Erwinia milletiae (Kawakami and Yoshida) Magrou 1937 (3, 5, 17), Erwinia lathyri (Manns and Taubenhaus) Magrou 1938 $(3,5,17)$, Erwinia cassavae (Hansford) Burk- holder $1948(3,5,17)$, Bacterium typhi flavum Breed 1948, Xanthomonas trifolii (Hüss) James 1955 (19), Escherichia adecarboxylata Leclerc 1962 (22) (ATCC 23216: a typical strain of E. agglomerans biogroup G3), Erwinia uredovora Dye 1963 (3, 5, 17), Erwinia herbicola (Düggeli) Dye 1964 (10), Xanthomonas herbicola Gorlenko $1965(3,5,17)$.

$E$. agglomerans apparently is a saprophytic microorganism occurring mainly on plant surfaces. It has been isolated frequently from plants, flowers, and seeds, but the consensus appears to be that, with the possible exception of the bacterium described under the name Erwinia uredovora (v. sup.), the bacteria are not phytopathogenic in the usual sense of the word $(17,20)$. However, Lasko and Starr $(21)$ have reported upon the ability of some of these, and certain other bacteria, to cause harmful effects in plants (injuriousness to plant tissues), and for the purposes of their discussion these investigators make a distinction between injuriousness and phytopathogenicity. They reported that certain Enterobacteriaceae, which ordinarily are not thought of as being phytopathogenic, are capable of producing injury to plant tissues.

$E$. agglomerans has been isolated from a wide variety of environmental sources and from various kinds of specimens from man and lower animals. As is the case with a number of other bacterial species, it is an opportunist and, when introduced into the tissues of man or other animals, may cause infection, sometimes severe and occasionally fatal. As might be expected, the serious infections often are in persons with underlying disease and in the young.

Investigators are reminded that microorganisms of other species of Enterobacteriaceae and members of certain genera of other families (e.g., Flavobacterium) may produce yellow pigment. For example, chromogenic (yellow) strains of Escherichia coli and $E$. cloacae occasionally are encountered. This subject, as well as the means for differentiation of E. agglomerans and all other recognized species of Enterobacteriaceae, is dealt with in the publication by Ewing (CDC Publ., in press).

\section{ACKNOWLEDGMENTS}

We are indebted to Dennis C. Graham (Department of Agriculture and Fisheries for Scotland, Agricultural Scientific Services, East Craigs, Edinburgh EH 12 8NJ) for cultures and for the translation of the relevant portions of Professor Beijerinck's papers which were unavailable to us and to $H$. Hatt, American Type Culture Collection, for the photomicrographs of the flagellated cells. 


\section{LITERATURE CITED}

1. Beijerinck, M. W. 1888. Cultur des Bacillus radicicola aus den Knollchen. Bot. Ztg. 46:740-750.

2. Beijerinck, M. W., and A. Rant. 1905. Wundreiz Parasitismus und Gummifluss bei den Amygdaleen. Zentralbl. Bakteriol. Parasitenk. Infektionskr. Abt. II 11:366-375.

3. Breed, R. S., E. D. G. Murray, and A. P. Hitchens. 1948. Bergey's manual of determinative bacteriology, 6th ed. The Williams \& Wilkins Co., Baltimore.

4. Breed, R. S., E. D. G. Murray, and N. R. Smith. 1957. Bergey's manual of determinative bacteriology, 7 th ed. The Williams \& Wilkins Co., Baltimore.

5. Buchanan, R. E., J. G. Holt, and E. F. Lessel. 1966. Index bergeyana, p. 888. The Williams \& Wilkins Co., Baltimore.

6. Cruickshank, J. C. 1935. A study of the so-called Bacterium typhiflavum. J. Hyg. 35:354-371.

7. Dowson, W. J. 1957. Plant diseases due to bacteria, 2nd ed. Cambridge University Press, London.

8. Dresel, E. G., and U. Stickl. 1928. Uber reversible Mutationsformen der Typhusbazillen beim Menchen. Deut. Med. Wochenschr. 54:517-519.

9. Düggeli, M. 1904. Die Baktereinflora gesunder Samen und daraus gezogener Keimpflanzchen. Zentralbl. Bakteriol. Parasitenk. Infektionskr. Abt. II 12:602-614; 13:56-63, 198-207.

10. Dye, D. W. 1964. Taxonomic position of Xanthomonas trifolii (Hüss, 1907) James, 1955. N.Z. J. Sci. 7:261-269.

11. Ewing, W. H. 1967. Revised definitions for the family Enterobacteriaceae, its tribes and genera. National Center for Communicable Disease, Atlanta.

12. Ewing, W. H., and B. R. Davis. 1970. Media and tests for differentiation of Enterobacteriaceae. Center for Disease Control. January.

13. Ewing, W. H., and P. R. Edwards. 1972. Identi- fication of Enterobacteriaceae, 3rd ed. Burgess Publishing Co., Minneapolis.

14. Fife, M. A., W. H. Ewing, and B. R. Davis. 1965. The biochemical reactions of the tribe Klebsielleae. National Center for Communicable Diseases, Atlanta.

15. Graham, D. C., and W. J. Dowson. 1960. The coliform bacteria associated with potato black-leg and other soft rots. II. Biochemical characteristics of low- and high-temperature strains. Ann. Appl. Biol. 48:58-64.

16. Graham, D. C. 1964. Taxonomy of the soft rot coliform bacteria. Ann. Rev. Phytopathol. 2:13-42.

17. Graham, D. C., and W. Hodgkiss. 1967. Identity of gram negative, yellow pigmented, fermentative bacteria isolated from plants and animals. J. Appl. Bacteriol. 30:175-189.

18. Hüss, H. 1907. Morphologisch-physiologische studien über zwei aroma-bildende bakterien Bacillus esterificus Maasen, und Pseudomonas trifolii sp. nov. Zentralbl. Bakteriol. Parasitenk. Infektionskr. Abt. II 19:50-70; 149

19. James, N. 1955. Yellow chromogenic bacteria on wheat. II. Determinative studies. Can. J. Microbiol. 1:479-485.

20. Komagata, K., Y. Tamagawa, and H. Iizuka. 1968. Characteristics of Erwinia herbicola. J. Gen. Appl. Microbiol. 14:19-37.

21. Lasko, J. U., and M. P. Starr. 1970. Comparative injuriousness to plants of Erwinia spp. and other Enterobacteria from plants and animals. J. Appl. Bacteriol. 33:692-707.

22. LeClerc, H. 1962. Etude biochemique d'Enterobacteriaceae pigmentées. Ann. Inst. Pasteur (Paris) 102:726-741.

23. Muraschi, T. F., M. Friend, and D. Bolles. 1965. Erwinia-like microorganisms isolated from animal and human hosts. Appl. Microbiol. 13:128-131.

24. Waldee, E. L. 1945. Comparative studies of some peritrichous phytopathogenic bacteria. Iowa State Coll. J. Sci. 19:435-484. 